\title{
TOBAT DALAM PERSPEKTIF ALQURAN
}

\author{
M. Sadik \\ STAIN Datokarama Palu, Jl. Diponegoro 23 Palu \\ e-mail:mohsadik@ymail.com
}

\begin{abstract}
Artikel ini membahas taubat dalam perspektif Alquran. Kata taubah beserta derivasinya berulang sebanyak 85 kali dalam Alquran. Taubat berarti kembali kepada Allah dengan segala ketundukan dan berjanji tidak akan kembali melakukan hal-hal yang dilarang oleh-Nya. Taubat dilakukan setelah seseorang melakukan kesalahan dan dosa. Lebih lanjut, taubat dilakukan sebagai suatu kewajiban dan sarana pendekatan diri kepada Allah sebagai realisasi keimanan terhadap-Nya.

This article deals with repent in the perspective of the Qur'an. The word taubah and the root words of it was found 85 times in the Qur'an with its derivations. Taubah means returning to God with obedience and commitment not to commit the offences forbidden by God. Taubah will be performed after a man or a woman has committed the offences and sins. In addition, taubah is performed as an obligation and medium to approach God as a realization of one's faith in God.
\end{abstract}

Kata Kunci: Taubat, dosa, Alquran

\section{PENDAHULUAN}

Dosa sebagaimana digambarkan oleh Rasulullah ibarat noda hitam di dalam hati. Kian banyak noda hitam dalam hati, maka hati bisa menjadi hitam legam dan kelam. Sinarnya, bukan hanya redup, 
tapi gelap. Cahayanya tertutup oleh titik-titik noda yang menjadikannya tak mampu lagi memandang dan menimbang kebenaran. Bila seseorang melepaskan diri dari dosa, memohon ampun dan bertobat, hatinya akan cemerlang seperti semula. Tapi bila ia mengulangi perbuatan dosa, maka noda hitam itu akan bertambah hingga meliputi hatinya (Nursani, 2005:81).

Meskipun demikian, kemaksiatan bukanlah akhir dari segalanya. Melakukan dosa tidak berarti jatuh yang tidak mungkin lagi baginya pelakunya untuk bangkit kembali. Inti yang ingin disampaikan dalam pesan hadis di atas, adalah seruan untuk mengulang-ulang dan memperbarui tobat. Kemaksiatan dan dosa, kemungkinan dapat menjadi pintu kebaikan bagi pelakunya, sebagaimana Adam as. yang merasakan kedekatan dan ketergantungannya yang luar biasa kepada Allah swt., ketika ia berbuat kesalahan. Karena itulah, doa Nabi Adam as. bersama istrinya disebutkan dalam Alquran QS. (7):23:

\footnotetext{
"Keduanya berkata: Ya Tuhan kami, kami telah menganiaya diri kami sendiri dan jika Engkau tidak mengampuni kami, dan memberi rahmat kepada kami, niscaya pastilah kami termasuk orang-orang yang merugi".
}

Dalam Alquran ditemukan banyak kisah terkait dengan mereka yang berbuat dosa dan kemaksiatan. Di antaranya ada yang bertobat, tetapi ada pula yang tetap dalam pelanggaran dan kesalahannya, sampai kemurkaan dan siksaan Allah swt. ditimpakan kepada mereka.

Dosa dan tobat ibarat dua sisi mata uang yang tidak dapat dipisahkan. Artinya, seharusnya mereka yang berdosa, bertobat dan memohon ampun kepada Allah swt. Dengan begitu, ia akan kembali kepada-Nya dalam keadaan suci, seperti keadaannya semula. Meskipun dosa dan kesalahannya, sampai memenuhi jagat raya. Bagaimana Alquran membahasnya?. Tulisan ini akan menguraikannya dalam perspektif Alquran. Pokok permasalahan dalam tulisan ini dapat dijabarkan sebagai berikut: Bagaimana konsep tobat dalam Alquran?; Apakah orang yang bertobat disebabkan oleh perbuatan dosa dan maksiat yang dilakukannya, sehingga tobat itu dimaksudkan hanya bagi mereka yang berdosa dan bersalah. Kalau itu benar, bagaimana orang yang tidak berbuat dosa, apakah tidak perlu bertobat?; (Sampai kapankah pintu tobat terbuka bagi seseorang?; dan Jika tobat 
dilakukan, apa implikasi yang diperoleh bagi mereka yang melaksanakan tobat?

\section{MAKNA TOBAT}

Kata tobat berasal dari bahasa Arab taubah yang merupakan bentuk mashdar dari fi'il ślasi mujarrad, taba, yatubu, taubah. Kata tersebut berakar dari huruf ta - wau - dan $b a$ yang memiliki makna dasar al-ruj-' (kembali). Misalnya, taba min zanbih, maknanya raja'a 'anhu (telah kembali dari dosanya). (Ibn Zakariya, 1991:357).

Secara leksikal, taubah berarti "al-ruj-'u min al-zanbi (kembali dari perbuatan dosa)". Misalnya, "wa taba ilallahi yat-bu mataban taubatan" bermakna "anaba wa raja'a 'anil ma'shiyat ila al-tha'ah (telah kembali dari maksiat menuju ketaatan). Kata tersebut juga berarti "al-nadm" (menyesal). Setiap orang yang menyesali perbuatannya disebut bertobat (Ibn Mandzur, 1972:90).

Dengan demikian, secara leksikal tobat berarti kembali. Yakni, kembali kepada Allah dengan penuh ketaatan dan ketundukan, serta meninggalkan larangan-Nya. Selain itu, tobat berarti menyesali. Yakni menyesali perbuatan yang telah dilakukan seseorang karena ia menyadari bahwa perbuatannya itu adalah bertentangan dengan kehendak dan keridaan Allah swt. Dengan demikian, persyaratan penting bagi seseorang yang ingin diampuni dosa dan kesalahannya adalah ia tidak lagi melakukan perbuatan dosa dan kesalahannya ialah ia melakukan amal kebaikan yang sebelumnya ia tinggalkan; dan ia menyesali perbuatan dosa yang pernah ia lakukan.

Term tobat dan kata-kata yang seakar dengannya ditemukan dalam Alquran sebanyak 85 kali dengan berbagai derivasinya. Ada yang berbentuk kata kerja, baik bentuk lampau, bentuk sedang, maupun bentuk perintah. Ada juga yang berbentuk mashdar, berbentuk isim fa'il, berbentuk musyabbahat bi ism fa'il, dan berbentuk isim makan. Hal tersebut dapat dirinci sebagai berikut.

Dalam bentuk kata kerja $\left(f{ }^{\prime}{ }^{\prime} i\right)$, tobat terdiri atas : 33 kata kerja bentuk lampau ( $f$ ' 'il madhi) dengan rincian: kata taba 17 kali yaitu : Q.S. 2:37, 54, dan 187. 5:39 dan 71. 6:54. 9:117, dan 118. 11:112. 19:60. 20:82, dan 122. 25:70, dan 71. 28:67. 58:13. 73:20. Kata taba 1 kali yaitu Q.S. 4:16. $t \pm b$ - 10 kali yaitu Q.S. 2:160. 3:89. 4:146. 5:34. 7:153. 9:5, dan 11. 16:119. 24:5. 40:7. Kata tubtu 3 kali yaitu Q.S. 4:18. 7:143. 46:15. Kata tubtum 2 kali yaitu Q.S. 2:279. 9:3. 
Sedangkan term tobat dalam bentuk kata kerja sedang/akan ( $f i^{\prime} i l$ mudhari') sebanyak 20 kali dengan rincian : kata at-bu 1 kali yaitu Q.S. 2:160. Kata tat-ba 1 kali yaitu Q.S. 66:4. Kata yatub 1 kali yaitu 49:11. Kata yat-bu/a sebanyak 11 kali yaitu Q.S. 4:17, 26, dan 27. 5:39. 9:15, 27, 102, dan 106. 25:71. 33:24, dan 73. Kata yat-b- 3 kali yaitu Q.S. 9:74, dan 118. 85:10. Kata yat-b-na 3 kali yaitu Q.S. 4:17. 5:74. 9:126. Term tobat dalam bentuk perintah ( $f$ ' $i l$ amr) sebanyak 8 kali dengan rincian : kata $t u b 1$ kali yaitu Q.S. 2:128. Kata $t-b-7$ kali yaitu Q.S. 2:54. 11:3, 52, 61, dan 90. 24:31. 66:8.

Bentuk isim fa'il sebanyak 2 kali dengan rincian: 1 kali kata altaibat (bentuk jama' muannas salim) terdapat dalam Q.S. 66:5, dan 1 kali kata al-taibin (bentuk jama' muzakkar salim) terdapat dalam Q.S. 9:112; bentuk musyabbahat bi ism fa'il dijumpai sebanyak 12 kali dengan rincian: kata tawwab 8 kali terdapat dalam Q.S. 2:37, 54, 128 dan 160. 9:104 dan 118. 24:10 dan 49:12. Kata tawwaban disebut sebanyak 3 kali, yaitu pada Q.S. 4:16 dan 64. 10:3. Dan kata altawwab ${ }^{3} n$ disebut 1 kali yaitu pada Q.S. 2:222, dan yang berbentuk mashdar dijumpai sebanyak 8 kali dengan rincian: kata al-taub (mashdar muzakkar) 1 kali yaitu pada Q.S. 40:3. Kata altaubatu/taubatu (mashdar muannas ) sebanyak 7 kali, yaitu pada Q.S. 4:17, 18, 92. 9:104. 42:25. 66:8 dan 3:90.

Berbentuk isim makan sebanyak 2 kali dengan rincian: kata matab 1 kali, yaitu pada Q.S. 13:30; kata mataban 1 kali, yaitu pada Q.S. 25:71

Kata tobat dalam bentuk isim fa'il mengandung makna orang atau pelaku dari tobat, dan perbuatan tobat baginya merupakan kebiasaan atau perbuatan yang telah menjadi karakteristiknya. Sedang kata tobat dalam bentuk musyabbahat bi ism fa'il, bila dalam bentuk mufrad (tunggal), maka kata tersebut bermakna Tuhan sebagai zat yang benar-benar menerima tobat hamba-Nya. Ia dinamai tawwab karena Ia kembali kepada hamba-Nya yang bertobat dengan ampunan ('ada alaihi bi al-maghfirah) (Ibn Mandzur, 1972:277).

Kata tawwabin (Q.S. 2:222) digunakan dalam makna hamba yang sungguh-sungguh bertobat atau hamba Allah yang banyak bertobat (Munawwir 1997:141). Artinya, tobat benar-benar menjadi bagian hidup dan kejiwaannya.

Berdasarkan penjelasan di atas, dapat ditegaskan bahwa tobat pada hakekatnya adalah kembali kepada Allah swt, baik karena 
adanya kesalahan dan penyimpangan yang dilakukannya, maupun karena kewajibannya sebagai hamba Allah yang menggantungkan hidup kepada-Nya.

Dengan demikian, tobat merupakan medium bagi seorang hamba untuk melebur kesalahan dan dosa-dosanya. Di samping itu, ia merupakan parameter untuk melihat fenomena keimanan seorang muslim, sekaligus sebagai wahana untuk mendekatkan diri kepada Allah swt. Karena itu, dijumpai dalam Alquran banyak ayat yang memerintahkan untuk bertobat kepada Allah swt.

Perintah bertobat dalam Alquran dengan memakai kata fi'il amr berulang sebanyak 8 kali, yaitu pada Q.S 2:54 dan 128. 11:3, 52, 61 dan 90. 24:31. Dan 66:8. Sementara dalam kaidah ushul dikatakan "al-amru li al-wujub" (perintah menunjukkan wajib) selama tidak ada indikator lain yang menunjukkan perubahan hukumnya. Jika demikian, bertobat wajib hukumnya. Untuk memperjelas hal tersebut perlu dirujuk berbagai kitab.

Al-Amidi (1402 H:100) berpandangan bahwa tobat hukumnya wajib sebagai akibat adanya bentuk kata perintah, sehingga tidak ada perbedaan antara wajib ain dan wajib kifayah dari sisi wajibnya. Esensi keduanya merupakan kewajiban yang sama-sama harus diamalkan. Artinya, kewajiban apapun wujudnya, baik wajib 'ain maupun wajib kifayah, keduanya merupakan kewajiban yang tidak dapat ditinggalkan.

Al-Alusi (1994:215) mengatakan, perintah bertobat dalam ayatayat Alquran adalah perintah wajib dan merupakan fardhu 'ain bagi seluruh umat. Dan dipertegas lagi oleh al-Zuhaili (1990:226) yang mengatakan bahwa tobat itu wajib dan kewajibannya merupakan kewajiban mutlak.

Dengan demikian, dapat dipahami bahwa tobat merupakan kewajiban mutlak bagi semua orang yang beriman, baik laki-laki maupun perempuan, karena manusia pada dasarnya secara alamiyah, identik dengan kesalahan dan dosa, sebagaimana kata pepatah "summiyal insaanu linis-yaanih" (manusia dinamai manusia karena sifatnya yang lalai).

\section{KATA-KATA YANG SEMAKNA DENGAN KATA TAUBAH}

Selain kata taubah, Alquran juga mengemukakan kata-kata yang sinonim dengan kata taubah yakni inabah, dan aubah. Kata-kata 
in \pm bah dalam berbagai turunannya ditemukan dalam Alquran sebanyak 18 kali (Q.S. 13:27. 31:15. 38:24 dan 34. 39:17. 60:4. 11:88. 42:10. 40:13. 42:13. 39:54. 11:75. 34:9. 50:8, dan 33. 39:8. Dan 30:31 dan 33). Dan kata-kata aubah dengan berbagai derivasinya sebanyak 16 kali (Q.S. 34:10. 88:25. 38:17, 19, 25, 30, 40, 44, 49 dan 55. 50:32. 17:25. 13:29, dan 36. Dan 78:22, dan 39).

Kata inabah dan aubah secara leksikal, searti dengan kata taubah yakni 'al-ruj-' (kembali) (Zakariya, 1991:152). Meskipun di dalam Alquran tidak ditemukan penjelasan secara ekplisit perbedaan ketiga kata tersebut. Namun, jika diperhatikan redaksi dan munasabat ayat, maka ketiganya mempunyai perbedaan. Taubat lebih beriorientasi pada orang-orang yang sebelumnya melakukan pelanggaran berupa penyelewengan dan penyimpangan. Inabah lebih beriorientasi pada orang-orang yang ikhlas dalam ketaatan kepada Allah. Dan Aubah adalah orang-orang yang senantiasa banyak melakukan ketaatan, ibadah, dan permohonan ampun kepada Tuhan (al-Maraghi, t.th.: Juz 22:118 dan Juz 25:165-166).

Dalam Ensiklopedi Islam disebutkan bahwa tobat atau taubah adalah kembali dari kejahatan menuju kepada ketaatan, karena takut akan murka dan siksa Allah swt. Inabah adalah kembali dari yang baik kepada yang lebih baik karena mengharap pahala. Dan aubah adalah orang-orang yang bertobat bukan karena takut siksaan dan tidak pula karena mengharap tambahan pahala, tetapi karena mengikuti perintah Allah swt (Ensiklopedi Islam,1994, Jilid 5:111).

Sejalan dengan penjelasan di atas, al-Ghazali menguraikan bahwa taubah adalah maqam (tingkatan) yang dimiliki oleh orang awam. Artinya, orang-orang yang kembali dari dosa-dosa besar menuju ketaatan. Inabah adalah maqam para wali dan muqarrabin (orang yang dekat dengan Allah). Artinya, orang-orang yang kembali dari dosa-dosa kecil menuju kecintaan Allah. Dan aubah adalah maqam para nabi dan rasul. Artinya, orang-orang yang kembali dari jiwa sendiri menuju Allah Ta'ala, misalnya Nabi Ayyub as adalah orang yang banyak kembali kepada Allah (Ahmad,2005:113-114).

Jika demikian, bilamana dilihat dari tingkat kedekatannya dengan Allah, aubah atau awwab adalah orang sangat dekat dengan Allah, hatinya selalu tawajjuh kepada-Nya. Baginya, seolah-olah tidak ada tempat bagi makhluk, kecuali hanya Allah. Atau bagai anak 
kecil yang tidak ada ibu yang dikenalnya, kecuali hanya ibunya sendiri. Inabah atau munib adalah orang yang kedekatannya dengan Allah di bawah dari orang-orang awwab. Sedangkan taubah atau taib adalah orang yang sebelumnya, jauh dari Allah karena pelanggaranpelanggarannya, kemudian ia berusaha mendekat kepada Allah swt., agar ia kembali menjadi hamba yang dekat kepada-Nya.

\section{PINTU TOBAT}

Jika Allah tawwab (Maha Penerima tobat). Pertanyaan adalah, sampai kapan Allah menerima tobat hambanya. Jika ditelusuri secara seksama jawaban Alquran mengenai hal tersebut, maka dapat disimpulkan bahwa pintu rahmat dan pintu ampunan bagi hamba-Nya tetap terbuka hingga ; Pertama, hamba tersebut melihat balasan atas dosa dan kesalahannya di dunia. Kedua, hamba melihat balasan atas dosa dan kesalahannya di akhirat.

Pintu tobat sudah tertutup, jika telah datang azab dan laknat Allah di dunia, yaitu ketika seseorang sudah menyaksikan bencana yang menimpanya (Q.S. 40:84-85 dan Q.S. 10:90-91). Surah 40 ayat 84-85, berbicara tentang peristiwa yang menimpa umat terdahulu. Mereka bertobat tatkala menyaksikan azab yang datang kepada mereka. Mereka baru sadar dan menyatakan keimanannya, saat balasan atas dosa atau kesalahannya menimpa mereka. Namun, pintu tobat bagi mereka sudah tertutup. Sedang surah 10 ayat 90 - 91, menceriterakan kisah Fir'aun yang baru sadar dan beriman, bertobat dan menyesal, ketika ia sudah tak kuasa lagi, lari dan mengelak dari siksa-Nya, di saat-saat menjelang kematiannya di dalam lautan yang ganas. Namun, ia sudah terlambat, pintu tobat telah tertutup baginya. Sejalan dengan itu, Rasulullah bersabda "sesungguhnya Allah menerima tobat hamba-Nya sebelum rohnya tiba ditenggorokannya".

Dalam fakta, sering dijumpai orang baru sadar dan bertobat, ketika musibah atau bencana telah datang kepadanya, di saat ia tidak berdaya lagi, dan pada waktu yang sudah terlambat. Akan tetapi, terkadang pula didapati, justru sudah datang bencana, namun manusia tetap belum juga sadar, belum kembali dan taat kepada Allah, bahkan tampak semakin jauh dari-Nya, seperti keadaan jahiliyah moderen. Jahiliyah moderen sering beranggapan penyebab bencana adalah karena hukum alam. Semua kejadian di dunia hanya dihubungkan dengan sebab, tidak dihubungkannya dengan rabbul asbab (Tuhannya 
sebab). Misalnya, Jika terjadi banjir, mereka berkata ; sebabnya adalah penggundulan hutan atau erosi tanah yang menyebabkan pendangkalan sungai. Jika terjadi gempa, mereka berkata karena pergeseran lempengan batu. Apabila terjadi kebakaran, mereka berkata karena sambungan pendek listrik, dan seterusnya.

Pada hal semua yang disebutkan itu, jika direnungkan dan dihayati secara sungguh-sungguh, maka pasti dikatakan, bahwa sebabsebab itu hanyalah merupakan "penyebab antara" untuk menguji keimanan seseorang. Apakah yakin kepada khalik atau kepada makhluk. Yakin kepada kekuasaan Allah atau yakin kepada ciptaannya. Yakin kepada sebab atau kepada rabbul asbab. Jahiliyah moderen tidak menyadari, bahwa penyebab utama dari semua malapetaka adalah disebabkan kemurkaan rabbul asbab, akibat perbuatan dosa yang dilakukan olehnya sendiri.

Selanjutnya, pintu tobat juga sudah tertutup, ketika balasan Allah datang kepada orang-orang yang berbuat zalim dan berbuat dosa di akhirat. Ketika sudah menyaksikan beratnya balasan yang akan mereka terima, sehingga mereka menyesal, tapi penyesalan yang tak berguna (Q.S. 32:12- 14 dan 35:37).

Ayat-ayat di atas, menjelaskan keadaan orang-orang yang menerima siksaan Allah, karena pelanggaran dan dosa-dosanya. Mereka bertobat dan menyatakan penyesalannya, saat sudah melihat siksaan-Nya yang amat pedih di akhirat. Mereka berteriak-teriak ingin kembali ke bumi, untuk berbuat amal saleh. Namun, waktunya sudah terlambat, pintu tobat telah tertutup baginya. Bagaikan bayi yang sudah keluar dari perut ibunya, tidak akan mungkin kembali lagi ke dalam perut ibunya, meskipun ia cacat. Seandainya cacat, maka tetaplah cacat selamanya. Di dunia ada operasi plastik tapi di akhirat tidak, tapi harus diakui ciptaan Allah yang asli tidak akan pernah sama dengan operasi plastik ciptaan manusia. Karena itu, kata pepatah; "penyesalan dahulu pendapatan, penyesalan kemudian tak ada gunanya". Penyesalan tak guna pada akhir derita. Kata Roma Irama.

Jika demikian, seseorang hendaknya selalu waspada setiap waktu, setiap detik kapan dan di mana saja, ia harus memperbanyak istighfar, selalu memohon ampunan atas kekhilafan dan kesalahannya. Tidak menunggu sampai datang bencana dan malapetaka. Dan tidak menunggu sampai datang malaikat 'izrail, sang pencabut nyawa yang tidak mengenal suap dan kompromi. Demikian pula, tidak melihat 
apakah dosa besar atau kecil, dosa lahir atau dosa batin. Bagi awwabin, semua sama saja. Sekecil apapun dosa itu, bagi mereka adalah penyebab kemurkaan Allah yang berujung pada siksaan-Nya.

Bencana dan kematian, datang tak memberi kabar lebih dahulu. Tempat dan waktunya dalam rahasia Sang Khalik. Tetapi meskipun demikian, para psikolog mengatakan bahwa aba-aba yang diterima oleh sebagian makhluk, seperti berhijrahnya sekolompok binatang ke tempat lain, adalah isyarat akan datangnya bencana di tempat itu.

Demikian pula kematian, sebelum datang, pada hakekatnya ia telah memberitahukan kepada manusia tentang kapan waktu kedatangannya. Sebelumnya, ia telah mengirim utusan silih berganti, namun manusia tidak menyadarinya. Utusan-utusan tersebut berupa; rambut yang sudah putih, gigi yang sudah copot, mata yang sudah rabun, pendengaran yang sudah tuli, lutut dan pinggang yang sudah sakit-sakitan, kulit keriput, dan berbagai utusan lainnya. Semua itu merupakan utusan 'izrail yang tidak dihayati oleh manusia. Karena itu, setiap orang hendaknya bergegas dan bersegera tobat kepada Sang Maha Pencipta Yang Maha Perkasa, ketika terlanjur berbuat salah atau berbuat dosa, sebelum bencana dan kematian datang kepadanya.

\section{IMPLIKASI TOBAT}

Implikasi atau Fungsi tobat dapat ditemukan pada Q. S. 11:52. 71:10-12.

$$
\begin{aligned}
& \text { ويا قوم استخفـروا ربكم ثم توبوا إليه برسـل السماء عليكم مدرارا ويزدكم }
\end{aligned}
$$

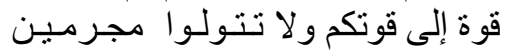

Terjemahnya:

Dan (Hud berkata), "Wahai kaumku! Mohonlah ampunan kepada Tuhanmu lalu bertobatlah kepada-Nya, Niscaya Dia menurunkan hujan yang sangat deras, Dia akan menambahkan kekuatan di atas kekuatanmu, dan janganlah kamu berpaling menjadi orang yang berdosa"

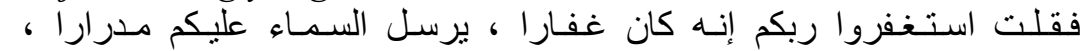

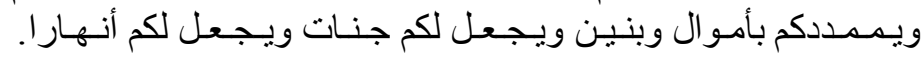

Terjemahnya:

Maka aku berkata (kepada mereka), "Mohonlah ampunan kepada Tuhanmu, sungguh, Dia Maha Pengampun. Niscaya Dia akan menurunkan hujan yang lebat dari langit kepadamu. Dan Dia memperbanyak harta dan anak-anakmu, dan 
mengadakan kebun-kebun untukmu, dan mengadakan sungaisungai untukmu

Dalam kedua ayat tersebut terdapat kata "istaghfir-", bentuk perintah (fi'il amr). Kata tersebut berasal dari kata ghafara-yaghfirughufrân. Kemudian mendapatkan tambahan hamzah, sin dan ta, maka menjadilah istaghfara-yastaghfiru-istighfâran, dan bentuk fi'il amr-nya (bentuk perintah), istaghfir yang bermakna isti'ânah (meminta). Kata tersebut dengan berbagai derivasinya berulang tidak kurang dari 40 kali. Hal ini menunjukkan perhatian Alquran agar seseorang selalu memohon ampunan kepada Allah swt.

Ghafara bermakna al-satru (menutupi), sebagai contoh "ghafarallâhu dhanbahû" (Allah menutupi dosanya). Kemudian menjadi fi'il mazid sudasi yang bermakna "thalaba minhu 'an yaghfira" (minta dari-Nya supaya ditutupi, dilebur dan diampuni dosanya).

Perintah bertobat dalam ayat di atas didahului oleh istighfar. Jika ini dipahami sebagai tartib (urutan), maka ia bermakna bahwa seseorang yang bertobat, sebelumnya ia harus beristighfar, memohon ampunan kepada Allah. Kalau demikian, keduanya tidak dapat dipisahkan, melainkan merupakan satu rangkaian dan satu kesatuan.

Jadi, orang yang ingin agar tobatnya diterima oleh Allah swt, ia harus banyak beristighfar. Mengulang-ulang ucapan istighfar, baik dengan lisan maupun dengan hatinya.

Al-Thabari (digital CD) menyatakan bahwa dengan ber-istighfar dosa-dosa seseorang akan ditutupi oleh Allah swt, yaitu beriman kepada-Nya, ikhlas dalam beribadah, bukan pada selain-Nya dan mengikuti petunjuk Nabi, kemudian meninggalkan perbuatanperbuatan yang dibenci Allah menuju perbuatan yang diridhai dan dicintai-Nya. Jika demikian, Dia akan memenuhi permohonan hamba.

Dengan pernyataan al-Thabari tersebut, istighfar bukan hanya sekedar ucapan meminta ampun kepada Allah agar diampuni dosanya, akan tetapi istighfar harus dimanifestasikan dalam wujud nyata, yaitu beriman kepada Allah dan ikhlas beribadah kepada-Nya, serta mengikuti petunjuk rasul-rasul-Nya. Jika demikian, maka istighfar saja tidak cukup, tetapi harus diiringi dengan tobat dalam arti menyesal, tidak akan mengulangi perbuatan masa lalunya, dan berbuat kebajikan. Istighfar tidak cukup dengan lisan, bahkan tidak cukup 
dengan mengumpulkan jama'ah sambil meneteskan air mata, namun harus disertai dengan tindakan nyata berupa ketaatan kepada Allah swt dengan menjalankan perintah-Nya dan mengikuti petunjuk rasul-Nya

Di celah-celah kedua ayat di atas ditemukan beberapa implikasi dari tobat. Muqātil berkata; ketika umat Nabi Nuh mendustakan nabinya, Allah pun menahan hujan, sehingga istri-istri mereka jadi mandul selama 40 tahun, ternak mereka binasa, dan tanamannya hancur. Mereka pun pergi ke Nabi Nuh untuk memohonkan hujan. Nuh berkata; mohonlah ampunan kepada Tuhanmu. Selanjutnya sebagai dorongan kepada mereka ia berkata; Tuhanmu akan memberikan harta, anak-anak, dan tanaman yang subur.

Ketika menafsirkan ayat di atas, Qatādah berkata; "Rasulullah saw mengetahui bahwa di antara umatnya terdapat orang yang sangat serakah terhadap harta, maka dia berkata: marilah kepada ketaatan kepada Allah, karena dunia dan akhirat pasti diperoleh melalui ketaatan kepada-Nya".

Selanjutnya, Ibn Katsir mengatakan, ayat tersebut bermakna, jika kalian bertobat kepada Allah, memohon ampunan dan mentaatiNya, maka Ia memperbanyak rezki kalian, meminumkan keberkahan hujan dari langit, menumbuhkan keberkahan dari bumi, menumbuhkan tanam-tanaman, menghilangkan kelemahan, memberikan harta, anak-anak, kebun dengan berbagai macam buahbuahan, dan sungai-sungai yang mengalir di dalamnya. Artinya, semua masalah dapat diselesaikan dengan tobat dan istighfar.

Bertolak dari penjelasan di atas, dapat disimpulkan bahwa dosa dan maksiat merupakan penyebab datangnya berbagai bencana dan malapetaka, baik dosa dan maksiat itu bersifat pribadi maupun bersifat kolektif. Solusinya adalah istighfar dan tobat yang sungguh-sungguh, kembali kepada Allah dalam arti menjalankan semua perintah dan menjauhi semua larangan-Nya.

Dosa dan maksiat ibarat awan yang naik kelangit, kemudian membentuk seperti gumpalan-gumpalan hitam yang tebal. Sampai pada batas tertentu, ia pun akan turun kembali ke bumi berupa bencana dan malapetaka, seperti kekeringan, banjir, longsor, badai, penghancuran massal, kekalahan dari musuh, disintegrasi bangsa, dan sebagainya. 
Itu sebabnya, ketika sahabat-sahabat Rasulullah saw. menaklukkan Kota Cyprus, Abu Darda seorang diri bersedih dan menangis, sementara yang lainnya bersuka cita menyambut kemenangan mereka. Ketika ditanya tentang kesedihannya, ia pun menjawab, bahwa bangsa yang mereka kalahkan hari ini, sebelumnya adalah bangsa yang berkuasa, bangsa yang menang, bagi mereka kerajaan, tetapi mereka meninggalkan perintah Allah, maka jadilah hari ini seperti yang disaksikan (Al-Kandahlawi,2004:1035).

Dari riwayat Abu Darda di atas dapat ditarik kesimpulan bahwa siapa saja yang melakukan pelanggaran terhadap perintah-perintah Allah, mengerjakan maksiat sehingga ia berdosa, ia pasti menemui kegagalan, keterbelakangan dan kehancuran. Karena itu, ketika terlanjur berbuat kesalahan dan dosa, maka seharusnya segera bertobat dan kembali kepada Allah swt.

Jika ini dikaitkan dengan kondisi bangsa kita saat ini, di mana krisis yang berkepanjangan terus berlanjut, silih berganti, tidak diketahui kapan akhirnya, pada hal penduduk mayoritas adalah umat Islam yang mengaku beriman. Bukankah Allah telah berjanji kepada orang-orang yang beriman untuk menolongnya dunia dan akhirat, sebagaimana orang beriman di zaman dahulu (Q.S. 40:51).

Secara faktual diakui bahwa meskipun banyak pesantren dan mesjid, marak pula pelanggaran seperti perjudian, pergaulan bebas, perzinahan, korupsi, tempat-tempat hiburan malam dengan kupu-kupu malamnya, dan berbagai bentuk pelanggaran lainnya. Semua itu mengindikasikan rusaknya akidah, ibadah, mu'amalah, muasyarah dan akhlak. Jika demikian, solusi dari semua peristiwa ini adalah kembali kepada Allah swt., bertobat dengan kembali melaksanakan perintahNya dan mengikuti rasul-Nya.

\section{PENUTUP}

Berdasarkan uraian sebelumnya dapat disimpulkan bahwa tobat bermakna "al-ruj-" (kembali), yaitu kembali kepada Allah dengan ketaatan dan ketundukan serta meninggalkan perbuatan yang dilarang oleh-Nya. Secara umum, tobat dilakukan setelah berbuat pelanggaran dan dosa. Tetapi tidak selalu harus demikian, tobat juga dilakukan sebagai bentuk kewajiban dan medium pendekatan diri kepada Allah swt sebagai realisasi keimanan seorang hamba kepada Tuhan-Nya. Pintu tobat telah tertutup bagi seseorang hingga ia melihat secara 
langsung (musyâhadah) terhadap balasan atas dosa, pelanggaran, penyimpangan dan kesalahannya, baik ketika di dunia maupun ketika di akhirat. Tobat yang sungguh-sungguh dapat menjadi solusi atas berbagai krisis dan permasalahan yang menimpa manusia, baik yang bersifat pribadi maupun bersifat kolektif.

\section{DAFTAR PUSTAKA}

Ahmad, Abdul Fattah Sayyid. 2005. al-Tasawwuf Baina al-Ghazali wa ibn Taimiyah, diterjemahkan oleh Muhammad Muchson Anasy. Tasawuf antara al-Ghazali dan Ibn Taimiyah. Jakarta; Khalifa

Al-Alūsiy, Abu al-Fadl Syihāb al-Din al-Sayyid Mahmūd. 1994. Rûh alMa'âniy fî̀ Tafsîr al-Qur'ân al-'Azîm wa al-Sab'u al-Mathânî, Jilid IX, Bairut: Dar al-Fikr.

Al-Amìì, 'Ā $\overline{l i}$ ibn Muhammad. 1402 H. al-Ihkâm fî Usûl al-Ahkâm, Juz I, Bairut: al-Maktabah al-Islâmiy.

Anis, Ibrāhìm, et al, al-Mu'jam al-Wasît, 1972, Kairo; t.p î

Ibn Manzuūr, t.th, Lisân al- 'Arab al-Muhît: Mu'jam Lughawiy 'Ilmiy, Jilid I, Bairut: Dār Lisān al-‘Arab.

Al-Kandahlawiy, Muhammad Yusuf. 2004. Hayât al-Șahâabah, Cet. I, Bairut: Dâr al-Kitâb al-'Arabiy.

Al-Maraghi, Ahmad Mushthafa. T.Th. Tafsîr al-Marâghî, Juz 22, Cairo; Dar al-Fikr.

Munawwir, Ahmad Warson. 1997. Kamus al-Munawwir, Surabaya; Pustaka Progressif.

Nursani, Muhammad. 2005. Mencari Mutiara di Dasar Hati, jakarta; Tarbawi Press.

Tim Penerbit. 1994. Ensiklopedi Islam, Jilid 5, Cet. III, Jakarta; Ichtiar Baru.

Tim Penyusun, Alquran dan Terjemahannya.

Al-'Ulama, Jama'atun min. 1990. al-Mishbâh al-Munîr fî̀ Tahzîb Tafsîr ibn Kasîr, Riyad: Dâr al-Salâm.

Al-Zuhailî, Wahbah. 1990. al-Tafsîr al-Munîr fî̀ al-'Aqîdah wa al-Syarî’ah wa al-Manhaj, Bairut; Dâr al-Fikr. 
Jurnal Hunafa, Vol. 7, No.2, Desember 2010: 209-222

Zakariya, Abu al-Husain Ahmad ibn Faris ibn, 1991. Mu'jam Maqâyis alLughah, Jilid I, Bairut: Dar al-Jil. 